\title{
Örselenen Kimlik İçin Sosyal Medyatik 'İyileșme/Normalleșme': Engelli Evlilik Topluluklarında Kimliğin 'Mürüvvetini' Görmek
}

\author{
Meltem Güzel ${ }^{1}$ \\ Savaș Keskin²
}

Öz

Bir grup çevrimiçi engelli bireyin sosyal medyayı örselenen/madun kimlikleri için telafi alanına dönüştürmelerinin kültürel bağlamını araştıran bu çalışmada, Facebook’ta örgütlenen 'Dostluk Arkadaşlık sohbet İzdivaç evlilik ve engelli aşk' topluluğu incelenmiştir. Evlilik ve flört temalı ilişkiler ekseninde engelli kimliğini normalleştirme/ iyileştirme faaliyetlerini kolektif olarak üreten üyelerden oluşan toplulukta, heterotopik bir kültür deneyimi de kurgulanmaktadır. Engelli kullanıcıların çevrimiçi birçok örgütlenmeyle öz-temsil edilmesine rağmen evlilik topluluklarının seçilmesinin 'normalleşme' ile evlilik arasındaki güçlü bağla ilişkisi vardır. Bekâr olmanın geleneksel yollardan ayıplanması ve toplumsal baskılar hesaba katıldığında, evliliğin özellikle engelli bireylerin 'normallik' kazanımları için önemi kavranabilir. Engelli kullanıcıların sosyal medyatik öz-temsilinin temasını oluşturan evlilik ve aşk ilişkilerinin örselenen kimliği onarmak için nasıl kurgulandığını açıklamayı amaçlayan çalışmada kültürel analitik perspektifi içeren netnografi yöntemi kullanılmıştır. Facebook’ta kültürel otonomi üreten çevrimiçi engelli grubun varlık gösterisini ele alan çalışmada, bireysel ve kolektif paylaşımlar temel alınarak bir dijital kimlik haritalaması denenmiştir. Çalışma bulguları, engelli kullanıcıların normalleşmeyi denedikleri sosyal medyada, örselenmenin ve madunluğun mevcut durumlarını da normalleştirdiklerini göstermektedir. Ayrıca, Araf'ta olma haline ve ileri marjinalliğe karşı sosyal medyayı ideal kimliğin 'heterotopyası' olarak kullanma davranışı da bulgular içerisinde önemli bir ayrıntıdır.

Anahtar Kelimeler: Öteki, Engelli, Kimlik, Sosyal Medya, Damga

Atıf: Güzel, M., Keskin, S. (2019). “Örselenen Kimlik Için Sosyal Medyatik 'İileșme/Normalleșme’ : Engelli Evlilik Topluluklarında Kimliğin 'Mürüvvetini' Görmek”. Akdeniz Üniversitesi Iletișim Fakültesi Dergisi, (AKiL) Aralık (32), s. 420-440

1 Öğr. Gör., İstanbul Üniversitesi Cerrahpaşa, Teknik Bilimler Meslek Yüksekokulu, Radyo ve Televizyon Teknolojisi Programı, ORCID ID: 0000-0002-1805-0490, meltem.guzel@istanbul.edu.tr.

2 Öğr. Gör., Bayburt Üniversitesi Sağılk Hizmetleri Meslek Yüksekokulu Yönetim ve Organizasyon Bölümü, ORCID ID: 0000-0003-0335-9062, savaskeskin@bayburt.edu.tr. 


\title{
'Improving/Normalizing' the Subordinated Identity Through Social Media: Coming to a Conclusion Successful in Normalizing the Identity in Marriage Groups for the Disabled
}

\begin{abstract}
A Facebook group titled 'Friendship Companionship Chatting Matrimony and Disabled Love' was analyzed in this study endeavoring to examine the cultural context of the case in which a group of online disabled individuals transformed the social media to make up for their subordinated identities. In this Facebook group which is composed of members collectively producing activities intended for normalizing/improving the identity of the disabled on the basis of relationships to be established to serve the purpose of marriage and flirting, a heterotrophic cultural experience is also configured. Even though disabled users are self-represented through several online organizations, the selection of marriage communities is associated with the strong link between 'normalization' and marriage. Only if the conventional dispraise for being single and the societal pressures are taken into consideration, then the importance of marriage especially to individuals' achievements of 'normality' can be understood. Netnography method which included global analytical perspective was utilized in the study intended for revealing as to how marriage and love relationships acting as the platform forthe selfrepresentation of disabled users via social media were configured in order to repair the subordinated identity. In the study addressing the online disabled group making its presence felt in Facebook by gaining cultural autonomy, attempts were made to create a mapping for digital identities on the basis of individual and collective posts. Findings of the study indicate that disabled users succeeded in normalizing the current state of feelings of subordination and inferiority in social media where they endeavored to achieve normalization. Moreover, the act of using social media as the heterotrophy of ideal identity against being stuck in the limbo and going ultra marginal is an important detail among findings of the study.
\end{abstract}

Keywords: The Other, The Disabled, Identity, Social Media, The Stigma

\section{Giriș}

Bu çalışmada, sosyal medya deneyimleri gözlemlenen bir grup çevrimiçi engelli bireyin 'evlenme amacıyla' kurduklarını varsaydıkları ve başkalarının da varsaymasını arzu ettikleri bir sosyalde kimlikleri için ve kimlikleriyle yapıp ettikleri üzerinde kültürel bir analitik uygulanmıştır. Goffman'ın 'itibarsızlaştırılmış olanlar ya da itibarsızlaşmaya müsait olanlar' (2014: s. 89) kategorisinde düşündüğü 'damgalı bireyler' arasında fiziksel engelliler için saptadığı konumun ağırlığı hesaplandığında, teorik bir ilhamla meseleyi bu bağlamda çözümlemeye çalışmanın da özgün bir açıklama oluşturacağı ifade edilebilir. Çünkü kimlikler arasında normal/seçkin olanı ayırt etmeye/belirlemeye yarayan kasti farklılıkların içerildiği küçümseyici ilişkiler dili olan damga tiplerinden yaygın olanı 'bedenin korkunçluklarını ve fiziksel bozunumlarını' (Goffman, 2014: s. 33) kapsar. Bedensel farklılıklar ve kusurlar ilk çağlardan günümüze kadar, toplumsal yapılar tarafından norm dışı olarak kabul edilir. Genel olarak belirlenen fiziksel özelliklerin 
dışında kalan, norm dışı olarak belirlenen bu fiziksel kusurlar ötekiliğin kapsamı içinde değerlendirilmektedir. Bunun en önemli gerekçesi; toplumların kurucu ilişkilerinde söz konusu normallikleri düzenleyen ve disiplin altında tutan denetim rejiminin gücünün/ iktidar olanaklarının yeniden üretildiği iç içe sosyal katmanları (Foucault, 1972-1977) arasında beden üzerinden idame edilen 'bio-iktidar pratiklerinin' (Rabinow \& Rose, 2006) kendi politik hafızasını oluşturmasıyla da açıklanabilir. Bedenin seçkinci kontrolünün, sembolik sosyal kodlarla kurgulanan ideal beden tiplerinin, kıyafetlerin, saç düzenlerinin, cinsiyet rollerinin ve kilo kontrollerinin ötesinde sağlık, eğitim ve kalkınma alanlarında çekip çevrilen bio-politikalara uzandığını (Foucault, 1997: s. 74-76) düşünmenin engelli yurttaşların kimlikleriyle birlikte yüz yüze oldukları makro sorunları anlamaya yardımcı olduğu söylenebilir.

Engelliler üzerinden sürdürülen bio-politikaların geniş düzlemde tanınma ve kimlik sorunlarına yol açtığına değinen Foucault, tahakkümün neden olduğu marjinalliğin belirli mekânsal ayrışmalar ve mevkii sıkışmaları ürettiğini savunur (Tremain, 2005: s. 2025). Normalliğin referans alındığı kimlik ayrımlarında bedensel bozulmalar ve genetik teşhislerin ağırlığına dikkat eden bu görüş (Tremain, 2005: s. 195), gündelik yaşamın mobilize alanlarından dışlanan fiziksel engellilerin, stabil ve heterotopik mekanlardaki marjinalliklerinin geniş kapsamlı bir iktidar/güç ilişkisinin nihai halkası olduğundan emindir. Bedensel engellileri 'anormal' gören ve normallik kurgusunun dışında bırakan geleneksel tavrın (Nazlı, 2012) güncel bio-politikalara sirayet etmesinin yarattığı kimlik bunalımları ve marjinalleşme travmaları, giderek daha fazla gündelik yaşamdan çekilen ve anormal olduğuna ikna olmuş engelli kitleler sorununu tetiklemektedir. Ancak sosyal medyanın varlığı tam olarak bu noktada belirgin bir fark yaratarak, engelliler gibi dezavantajlı kimlik grupları için telafinin ve normalleşmenin yaratıldığı öztemsil alanları (Özmen \& Keskin, 2018) olarak öne çıkmaktadır. Çünkü Goffman'ın bakışıyla damgası olan engelli birey genellikle kendisi gibi olanlarla ya da en azından 'halden anlayanlarla' (2014: s. 51) bir araya gelerek 'normalmiş' gibi itibar görmeyi amaçlayabilir. Engelli bireyler mobilize topluma ayak uydurmakta zorlanmalarına karşın, mobil teknolojilerin olanaklarını kullanarak bulundukları mekânın ve fiziksel varoluşun kısıtlarını aşabilir. Diğerleriyle bir araya gelmenin, dayanışmanın ve cemiyet karmaşığını kendini referans alarak yeniden inşa etmenin esnekliğinde otonom bir kimlik inşa edebilir. Üstelik sosyal medyanın 'akışlar uzayında' (Castells, 2000) sınırların tesirini yitirmesi ve 'sayısal temsil' (Manovich, 2001: s. 27-30) yoluyla fiziksel bedenin koşul olmaktan çıkmasının ve sayısal bedenlenişin, beden üzerinden sürdürülen güç ilişkilerini eriten ve etkilerini azaltan olumsal sonuçları da vardır. Çünkü sayısal dolayımla sistem arayüzlerinde yeniden tanımlanan ve kurgulanan sosyo-dijital temsillerin gerçekliği, farklı bedenlenişler/suretler/izlenimler/somutlaşmalar yordamıyla yeni bir fenomenolojik hafıza ve algı üretebilir.

Yukarıda tarif edilen türden özel bir sosyal medya pratiğini irdeleyen bu çalışmada, engellilerin birçok öz-temsil örgütlenmesi arasında evlilik topluluğunun seçilmesi tesadüf değildir. Çünkü sosyal medyanın öz-örgütlenme prensiplerini kendi hesabına kullanarak birçok meşru kurgu üretmenin imkânı söz konusuyken, evliliğin ayrıcalıkıı bir yeri vardır. Goffman’a göre damgalı bireyler yetersiz olduğu düşünülen etkinliklerden birinde uzmanlaşarak kendini gerçekleştirmeyi ve normalliği tecrübe etmeyi amaçlaya- 
bilir. Bunun için uçak kullanmak, yüzmek, gezmek, tenis oynamak gibi faaliyetlerde kendini geliştirmeye çabalar (2014: s. 39). Evlilik ise tüm bu rutin aktiviteler dışında, toplumsal açıdan normalliğin en ideal ve kalıcı görünümlerinden, kişisel başarılarından biridir. Çünkü evlenmek, sosyalleşme evreleri içerisinde oldukça belirgin bir normallik fazı ya da eşiğidir. Bu nedenle geleneklerin ağır olduğu toplumlarda aile kurmanın ön şartı sayılan evlilik yaşı geldiğinde toplumsal baskı artar ve bekârlık ayıplanır (Poster, 1979; Weber, 1947). Oysa bu sosyal yasa engelliler için pek de geçerli sayılmaz. Çünkü filmografik hafıza ve diğer tüm geleneksel anlatılar yoklandığında, evlenecek eş seçiminde bedensel estetik ve tatminin arandığı (Meltzer, 2010) kolayca hatırlanabilir. Engelli bireyler, yukarıda açımlandığı gibi çoğu durumda anormal ve bakıma muhtaç addedildikleri için evlilik şartından muaf tutulma hakkına sahiptir. Bu nedenle evlenmek, engelliler için yalnızca hayat arkadaşı bulmakla sınırlı bir anlam değildir. Aynı anda imkânsıza yakın bir eşiği geçerek başarmış olmanın ve normalliğin ölçütüdür. Tüm bunların yanında, çeşitli mekânlara sıkışan bireylerin tanışmak, sosyalleşmek ve paylaşmak gibi 'normal' aktivitelerinde bulunması, flört ve evlilik ilişkileri talep etmesi de meşruluğun inşasında kimliğin nasıl kodlandığı hakkında haber verir. Çünkü sosyal medyadaki bedensizlik deneyimi, dijital gezginci bir mizaçla sürekli dolaşımda olmayı ve diğerleri ile etkileşmeyi teşvik eder (Keskin ve Kaya, 2018).

Bu çalışma kapsamında Facebook’ta örgütlenen engelli evlilik platformları içerisinde en fazla popülasyon ve sosyal trafik içeren 'Dostluk Arkadaşlık sohbet İzdivaç evlilik ve engelli aşk' sayfası (www.facebook.com/group) ekranında gerçekleşen kültür üretimi ve kimlik inşasının dijital görünümleri incelenmiştir. Sayfanın kapsamının birçok sosyalliği barındıracak biçimde esnetilmesi, sayfadaki 'normalleşme' ve 'kimliği onarma' faaliyetlerinin sosyal güdülenişini ve profilini yansıtmaktadır. İncelenen sosyal medyanın Facebook ile sınırlandırılmasında, engelli kullanıcıların bu tarz toplumsallaşmalar için Facebook'u tercih ettiklerinin tespiti, Facebook'un topluluk oluşumları için diğer platformlara göre daha işlevsel kültürel arayüzlerle tasarlanması ve 2019 itibariyle dünyada en fazla kullanılan sosyal medya platformu olması (Clement, 2019) gibi kıstaslar belirleyici olmuştur.

Bu çalışmada engelli kullanıcıların evlilik topluluklarındaki kültürel faaliyetlerinin, kimlik inşalarının ve normalliğe ilişkin yeniden üretimlerinin açıklanması amaçlanmaktadır. Bu amaç, sosyal medyada görece özerk kullanım haklarını ellerinde tutan ezgin kimliklerin normalliğin tahakküm boyutlarında hangi değişikliklere gideceği ya da kendi normalliklerini nasıl kurgulayacaklarını anlamaya yardım etmesi bakımından önemlidir. Çünkü topluluk sayfasındaki kültürel edimler, evliliğin öteki boyutlarını, siber kimlik deneyimleriyle başkalaşan ötekilik ilişkisini ve damgalanmış bireylerin normalleşme gayretlerini gösteren kodları barındırmaktadır. Bu yönüyle çalışma kapsamında şu sorulara yanıt aranmıştır.

- Engelli kullanıcıların evlilik iliş̧kileri ve diğer ilişkiler bağlamındaki paylaşım ağları ve ritüelleri sayfa içi dinamikle etkileşerek nasıl bir kültür kurar?

- Engelli kullanıcılar incelenen topluluk sayfası içinde kendileri ve 'kendilerinden olmayanlar' ile ilgili tam olarak ne yapmakla meşguldür?

- İncelenen topluluktaki evlilik ilişkileri dışına taşan kimlik aktiviteleri nasıl ve 
hangi zeminde oluşur; kimlik pratiğinin ne kadarına tesir eder?

- Normalleşmeye yönelik telafi faaliyetlerinin somut görünümleri nasıldır? Alt metinsel anormallikler nasıl tanımlanır?

Nitel veri paradigmasına göre işleyen bu çalışma, yukarıda belirtilen sorulara yanıt üretmesi hedeflenen bir kültür araştırması olarak modellenmektedir. Evliliği, kimliği ve benlik sunumlarını bir kültürün inşası olarak varsayan bu çalışmada, verilere ulaşma ve analiz etme metodu olarak netnografi kullanılmıştır. Sayfa içindeki paylaşımların bütününü, kültürel kodlar taşıyan davranış ve içerik sistemleri olarak değerlendiren çalışmada, paylaşım ilişkileri, grup dinamiği ve karşılıklı rol tanımları ekseninde bir kültür analitiği uygulanmaktadır.

\section{Kuramsal Art Alan: Damgalanmış Bedenin Hükmüne Karşı Sayısal Bedenleniş ve Sanal Kimliklenme}

Geleneksel yaşamda kimliğin özdüşünümselliğine bakıldığında bedenle yakın ilişkide olduğu görülebilir. Sanal topluluklar ve kimlik ilişkisi üzerine çalışan Donath (1998: s. 1), geleneksel topluluklarda kimlik denilince anlaşılması gereken şeyin beden olduğunu ve bir kimlik, bir beden normunun korunduğunu ifade eder. Nitekim varlık felsefesinin orijin aldığı argümanlar beden ve ruh arasındaki zinde ilişkilere dayalı bir kimlik türünün sembollerine başvurur. Bu noktada Bouerdieu (1985; 1986; 2002), Heidegger (2018), Levinas $(1998,2014)$ ya da Sartre (2009) gibi düşünürlerin bedenin mekânsal ve zamansal yeniden üretim olanakları ile ötekiliğin bedensel düşünümü, denetimini, varlık zaptını ve direnişin, dayanımın ve özgürleşmenin yine bedensel olanaklarını tartışmaları tesadüfi değildir. Bu tartışmada beden yalnızca dirimsel değildir; aynı zamanda semboliktir. Nitekim bedenin sosyolojisi gereğince her beden bir semboller sisteminin parçasıdır ve söylem pratiklerine bağlı olarak sosyal altyapı üzerinde kurulur (Cirhinlioğlu, 2001: s. 93). Bu yönüyle engelli bedenlerinin maduniyet ve damga sıfatlarını düşünürken söz konusu olan normallik, biyolojik olmaktan çok semboliktir.

Kimlik sendromlarının doğuşunu beraberinde getiren modernite, farkların ve farklı olanın dışlandığı (Connolly, 1995) yeni bir ilişkiyi tedavüle sokmuştur. Bu noktadan hareketle 'ben' ve 'diğerleri' ayrımını yaratan ötekileştirme kavramı, en basit haliyle düşünüldüğünde insanların farklılıkları üzerinden işleyen mücadeleci karaktere ve iktidar ilişkilerinin 'lekelerine/izlerine' sahiptir. Hancock (2000: s. 1), bedenin daim mücadelelerin yaşandığı, disiplin teşebbüslerinin ve direniş taktiklerinin odağında yer aldığını ifade ederken, Foucault'un (1992) bedensel gözetim, disiplin ve cezalandırma mekanizmalarını hapishaneler üzerinden anlatımını ve bio-iktidar (1997) yaklaşımını da çağrıştırır.

Engellilerin bedensel durumlarına başvurarak kurgulanan kimlik ilişkisine 'Damga Teorisi' ile açıklama üreten Goffman (2014) damgalamanın, birini diğerlerinden ayrı kılan ve onun istenmeyen, nahoş bir niteliği taşıdığını anlatan sosyal, görünmez ve söyleme dayalı sembolik bir "işaret" olduğunu izah eder. Damgalama karmaşık ve dolanık sosyal ilişkilerin pek çok boyutunda, farklı biçimlerde ve farklı kesimlerden bireylerin ya da grupların yaşadığı bir durum olarak ortaya çıkagelmektedir. Damgalanma 
(Stigmatization), bir grubun niteliklerinin mevcut bir sosyal grup tarafından değerinin düşürülmesi sürecine atıfta bulunur. Engelli birine yönelen 'özürlü', 'sakat', 'muhtaç', 'spastik' gibi tahkir edici/pejoratif damgalar, 'normal' olduklarına inanılan mümtaz kimliklerin kurumlanmalarına refakat eder. Engellilerin toplumsal konumlarını tayin eden kimliklerini betimleyici bir kritikle anlamaya gayret eden teoriğe göre muğlak bir profil ya da siluet anlaşılmaktadır. Goffman bu ikircikli pozisyonu ve ileri marjinalliği şöyle ifade eder (2014: s. 183);

Damgalının hususiyeti "sınıflandırılamaz" oluşudur; "normaller" dünyasına ait değildir ancak bu dünyaya yabancı da değildir. Fiziki açıdan tam olarak sağlıklı değildir ancak hasta da değildir (çünkü hastalık tanımı gereği geçici bir durumdur). Ölü değildir ancak canlılar dünyasına da ait değildir; toplumsal açıdan hem vardır hem yoktur.

Goffman'ın tespitleriyle engelli bireyin sosyal varlığı 'kayda değer bulunmayan', 'itibarsız', 'önemsiz' ve 'ikinci planda tutulan' bir konumda kendini kurmayı dener. Bu tarz bir kimlik deneyimi 'normal' sosyallikler içerisindeki engelli varlığını olanaksız hale getirir ve içe kapanmanın, elini eteğini çekmenin ve dışarıya atılmanın normalleşmeye başladığı sorunlu bir süreç yaşanır. Nihayetinde engelli bireyler engelli olduklarından daha çok, damgalarından dolayı 'engellere' maruz bırakılır. Kültürel tanımlardaki olumsuz etiketlemeler telafi edilmesi güç sosyal kayıplara neden olabilir (Goffman, 2014: s. 39-40). Engelliliğin söylemsel morfolojisini açıklayan biyolojik/tıbbi ve sosyal modeller, damganın işleyen çarklılarına göndermede bulunur. Tıbbi model, engellilik halini hastalık ve yeti kaybı olarak kabul edip engelliliği psikolojik ve biyolojik bozukluk olarak görmektedir. Söz konusu hastalığın tıbbi müdahale ile iyileştirilmesi gerektiğini savunmaktadır. Bu model, engelli bireylerin toplumsal hayatlarında maruz kaldıkları baskı ve dışlanma pratiklerini görmezden gelerek toplumsal ve kültürel çevrelerinin bireyleri engelledikleri gerçeği üzerinde durmamaktadır (Duman \& Doğanay, 2017: s. 7). Sosyal modelde ise damgaların işlevleri ve sentetik olarak inşa edilen kimlik engellerinin işgal ettiği tanınmanın boyutları ele alınmaktadır.

Fiziksel yoksunluğun çok daha ötesinde başka birçok nedene bağlı sınırlandırmaları da içeren engelli olma halini tanımlayan sorunlar sistematiği çerçevesinde üzerinde durulanlardan belki de en önemlileri eş bulma, evlilik planı yapma, arkadaşıı kurma üzerine olduğu sonucuna ulaşılmaktadır. Engelli bireylerin eş bulmadaki dezavantajı konumları engelleri odağında yaşadıkları sorunlarla şekillenmektedir. Buna göre bu sorunlar "ailelerin istememesi", "başkalarının dış görünüşe önem vermesi", "evliliğe ilişkin sorumlulukları yerine getirememe kaygısının başkalarınca duyulması" ve "ekonomik problemler" olarak belirtilmektedir. Engelli bireyler arkadaşlık kurma, kurdukları arkadaşlıkları sürdürme konusunda da bazı sorunları dile getirmektedirler. Özellikle karşı cinsle arkadaşlık kurmada, geliştirmede ve sürdürmede daha yoğun bireysel ve sosyal baskıları yaşamaktadırlar. Engelli bireyler cinsiyet fark etmeksizin arkadaşlık kurmada güçlük yaşama nedenlerini sırasıyla, "çekinme, kendine güvenmeme, beğenileceğini düşünmeme", "dışlanma/kabullenilmeme", "engelli olmanın getirdiği hareket kısıtılığına bağlı olarak arkadaş edinme olanaklarını yakalayamama", "kendini anlayabileceği kişilerle karşılaşamama", ve "yaşadığı maddi sıkıntılar" olarak dile getirmektedirler (Burcu, 2017: s. 116). 
Geleneksel, yüz yüze, fiili ya da gerçek gibi birçok isimle anılan organik topluluk döngüsünde yukarıdaki ifade edilen problemleri farklı kademelerde hisseden engelli bireyler, dezavantajlı kimlik gruplarının alternatif bir toplum simetrisi ve telafi sistemi olarak kullandığı sosyal medyada (Özmen ve Keskin, 2018: s. 539-540) kendini uyarlayarak onarıma ve olumsal kod inşasına girişebilir. Yüz yüze olduğu problemlerden bazılarının onulmaz vaziyetlerine rağmen birçok sosyal problemi ve söylemsel manipülasyonu lehine çevirme gücünü sosyal medyadaki topluluk ilişkilerinde bulan engelli bireyler, normalleşmenin, itibarın ve iyileşmenin 'umudunu', 'aldanışını' ya da 'gerçekliğini' (Wellman \& Gulia, 1999: s. 1) canlı tutma işine koyulur.

Sanal toplulukların üyelerine bedenlerin sınırlarını aşan esnek ve kişinin kontrolünde/ denetiminde şekillenen kimlikler isnat etmesi (Donath, 1998: s. 1) ve kişiye özgü sanal karakterin esnek dijital kodlar sayesinde kolaylıkla modellenmesi (Yanıklar, 2014: s. 166-168) gibi nedenler, geleneksel topluluklarda telafisi oldukça zor olan stabil/kronik kimlik modlarını her türlü olumsal müdahaleye açık hale getirir. Bu ağları kullanan engelli bireyler gerçek yaşamda ön plana çıkartılan kişisel ve bedensel özellikleri dışında kalan, kendi ön plana çıkarmak istedikleri özelliklerini ön plana çıkarabilmekte ve ötekileştirilmesine neden olan özelliklerini geri plana itebilmektedirler. Bu durumun en güçlü katalizörü, yeni medyanın temel prensipleri arasındaki 'sayısal temsildir'. Yeni medyanın dijital kodlarla yazılan kültürel arayüzlerinde temsil edilen tüm bileşenlerin sayısal kodlarla modellendiğine dayanan bu prensip gereği, tüm gerçeklik esnek ve sonsuz surette yaratılabilen bir mekanizmanın işleyişine göre sürekli yeniden biçimlenir (Manovich, 2001: s. 28-29). Sofistike öz-temsil tasarımlarla yeniden kurgulanan bedenin kusurlarından arınan bir görsel estetikle daha çekici hale gelmesi de (Manovich, 2016: s. 11-12) kaçınılmaz olarak engellilerin normallik kabullerine yakınlaşma/kimliği iyileştirme çabalarını motive eden cazip ayrıntılardan sayılabilir.

Sosyal ağ sitelerinin temsili karakteri, dolaysal bir süreçte kendini yenileyen ve yeni baştan kuran kullanıcının mekansızlık ve bedensizliği doğrudan yaşaması ve yoklamasıyla geniş̧leyen kültürler ve kimlik tipleri üretir. Sosyal medyanın mekansız ya da çoklu mekanlı, bedensiz ya da çoklu bedenli topluluk imkanları, geleneksel yaşam alanlarında var olmada ve ulaşım imkanları kullanmada zorluk yaşayan engelli bireyler için bu açıdan da bir avantaj durumuna gelmektedir. Çünkü bu yersiz-yurtsuz, ulusaşırı, yöresel olmayan, akış halindeki ve fiziksellik sınırlardan özerk (Castells, 2000; Fuchs, 2007; Fuchs, 2009) durumdaki sosyal alandaki sayısal bedenleniş olanakları, özgürlük hissini üst sınırlara taşıyabilir. Sanal topluluk üyelerinin bedensiz olmaya karşı istekleri (McDonald, 2006: s. 511) ile özgürleştirici topluluk hisleri ve gelenekselin ağırlığından kurtulma çabaları arasında ilişki kurulabilir. Sayısal bedenleniş dijital ve elle tutulamayan bir durum olduğu için varlığın somut delillerini üretmek için bedeni tarif eden multi-medya içeriklere başvurulur. Ancak bu enstrümanların ve içeriklerin ardındaki sayısal beden, kodlu yapısı sayesinde her an her yerde gezinen sınırsız ve suretsiz bir varoluştur. Üstelik engelli birey tek bir bedene bağlı kimliği yerine, çoklu ve birçok farklı özellikte kimliği (Manovich, 2016: s. 11-12), farklı kültürel arayüzlerde/ alanlarda eşzamanlı idare edebilir. 


\section{Yöntembilimsel Tasarım}

Bir kültür araştırması olarak modellenen bu çalışmada, kültürel verilerin analitiği ve anlamlı bulgular olarak kendilerini ifade edebilmesi için netnografi yöntemi kullanılmıştır. Çünkü bilgisayarlaşan kültürün Büyük veri sistemlerinde sürekli artan kültürel kodların tasnifi, ayrıştırılması ve anlaşılması için gerekli bilimsel paradigma, kültürel analitiklere yönelmeyi gerektirir (Manovich, 2012: s. 2).

Netnografi yönteminin tarihsel öncülü ve referans noktası olan Etnografi, temelde bir kültürün tanımlanmasını ve başka bir yaşam tarzını anlama çabasından türemiştir. Nitekim etnografi tarih boyunca 'öteki' olarak tanımlanan izole toplulukların yaşamları üzerindeki meraka ve gizeme ilaç olması gayesiyle kullanılagelmiştir. Öteki olanın bilinmezliğini bilinir kılmanın yollarından olan etnografide, incelenen grubun kültürel içgörüleri, kimlik algıları ve toplumsalı somut olarak kuran paylaşım ilişkilerinin görünen taraflarından köklere uzanan bir okuma süreci yaşanır. Netnografi yöntemi (çevrimiçi etnografi), etnografinin bilgisayar dolayımlı iletişim ortamlarına uyarlanması ve sanal ortamlardaki kültürel ilişkileri kapsayan uzantısıdır. (Binark, 2014: s. 138). Bu çalışma kapsamında, öteki oldukları gözlenen, saptanan ve varsayılan engelli bireylerin kurmakta oldukları çok sayıda telafi ve normalleşme devrelerinden biri olan evlilik topluluğunda tasarladıkları kültürel yaşamlarının anlaşılması amaçlanmaktadır.

Sanal topluluk sosyolojisinin 'tüketim' faaliyetlerini odağa alan ve bu tip oluşumları tüketici kitleler sınıfında yorumlayan bir anlayışla sahaya uyarlanan netnografi (Kozinets, 1998: s. 366), tüketici davranışlarını anlamlandırmak, demografi ve psikografi bileşenlerini satış stratejisine dönüştürmek için istenen ideal ölçümleri verir. $\mathrm{Bu}$ çalışmada engelli bireyler, üre-tüketici/prosumer (Fuchs 2017: s. 72) olarak kavramsallaşan 'hem üreten, hem tüketen', 'kendi ürettikleriyle birlikte başkalarının ürettiklerini tüketen', 'üreterek tüketmeye devam eden' kullanıcı taksonomisinin bir parçası olarak varsayılmaktadır. Kimliklerini yeniden üreten, bunu yaparken de gündelik ilişkileri içerisinde üretilenleri tüketen, ayrıca geleneksel olumsuz kodları tüketerek yeni kodları türeten, evliliğin yapısal özelliklerine dair tüm bilinenlerin yanında yeni keşfedilenleri de üretip-tüketen bir kullanıcı profili, normalliği koruyamayacağının bilinciyle sürekli üretmeyi dener. Çünkü geleneksel kodlar her ne kadar stabil ve katı ise, dijital kodlar bir o kadar geçici, esnek ve enformasyoneldir. Bu nedenle olumsuzluğun katı baskısı gibi, olumsallık ve normallik de her gün üretilmeli, tarih gereğince mücadele sürmelidir.

Netnografi yönetiminin uygulanışında gelenekleşen tedrici tahlil aşamaları bu çalışmada da uygulanmış ve yöntemin esaslarına sadık kalınmıştır. Bu doğrultuda, giriş ve planlama, verilerin toplanması, verilerin analizi, araştırma etiğinin sağlanması ve üye kontrolleri gerçekleştirilmiştir.

Giriş ve Araştırma Planlaması sürecinde, engelli bireylerin 'Dostluk Arkadaşlık sohbet İzdivaç evlilik ve engelli aşk' sayfası içindeki çevrimiçi kimlik aktivitelerinin geleneksel ilişkilerindeki sonuçlardan farklı bir dizi itibar birikimini, dayanışmayı, buluşmayı ve telafiyi beraberinde getirdiği varsayılmıştır. Bunun yanı sıra, engellilerin sosyal medya deneyimleri hakkında konuşabilmek için gerekli verilerin elde edileceği sahadaki üreticiler olarak engelli kullanıcıların, özlerini yansıtan ve samimi bir motivasyonla hareket 
ettikleri varsayımı da göz önünde tutulmuştur. Engelli evlilik gruplarının daha çok Facebook üzerinde yoğunlaştığını gösteren sondaj gözlemleri, bu platformun çalışma sahası olmasında belirleyici etkendir. Facebook üzerinde yapılan çalışmanın planlama safhasında, erişilebilen engelli evlilik siteleri incelenerek, çalışma grubu olarak üye sayısı yüksek ve veri çeşitliliği bakımından zengin olan 'Dostluk Arkadaşlık sohbet İzdivaç evlilik ve engelli aşk grubu' seçilmiştir. Bu grup, üyelerin diğer gruplara yönlendirildiği genel bir kamusal alandır. Bu grup yanında üyelerin yönlendirildiği alt gruplarından olan diğer evlilik grupları da incelenmiş ve ortak bir kültürün üretildiği izlekler ve sapaklar tespit edildiği için, en genel düzeyde fikir sahibi olmaya yardımcı olan, içerik bakımından zenginliğini sergileyen 'Dostluk Arkadaşlık sohbet İzdivaç evlilik ve engelli aşk grubu' verilerine sadık kalınmıştır.

Topluluk yaklaşık olarak 10 bin 150 üyesiyle ${ }^{3}$ benzer gruplarla karşılaştırıldığında popülasyonu en yüksek olan gruptur. Sayfaya üye olan katılımcılar incelendiğinde aynı kişilerin benzer diğer gruplarda da üye oldukları gözlemlenmektedir.

Çalışmanın ilgilendiği topluluk sayfası, yaklaşık 3 ay boyunca ön gözlemler yapılarak betimlenmiş, kodlar ve kültürel göstergeler birbirini tekrar etmeye başladığı ve genel kategoriler biçimlenmeye başladığında aksiyon safhası için adım atılmıştır.

Verilerin Toplanması sürecinde; sayfa içindeki yazılı ve görsel paylaşımlar günlük olarak, 1 Ocak 2019-1 Nisan 2019 tarihleri arasındaki 3 aylık zaman diliminde gözlemlenmiş ve kültürü yansıtan kodlar screenshot/ekran görüntüsü alma ve yazılı not alma tekniği ile kaydedilmiştir.

Topluluktaki temsil ve topluluk ilişkileri, üyelerin de yöneticiler gibi paylaşım yapabildikleri bir platformda gerçekleşmektedir. Kullanıcılar birbirlerinin paylaşımlarına beğeni, yorum yaparak ya da bu paylaşımları tekrar paylaşarak grup içerisindeki etkinliklerini sürdürmektedirler. Araştırma sırasında bu paylaşımlar ve paylaşımlara yapılan yorumlar detaylı olarak incelenerek sayfa yöneticileriyle enformel görüşmeler yapılmıştır. Bu görüşmelerin amacı, sayfada tam olarak tanımlanamayan ayrıntılara ışık tutmak ve topluluk yerlisinin görüşleri çerçevesinde toplumsal düzeneklere aşina olmaktır. Sosyal ilişkilerdeki ötekileşmeyi ortaya koyabilmek amacıyla, karşılıklı yapılan yorumlar incelenip araştırmayla ilgili olanlar kayıt altına alınmıştır. Kayıt altına alma işlemi sırasında ötekileştirici söylemler ve etiketlemeler özellikle göz önünde bulundurulmuştur. Aynı zamanda bazı paylaşımları yapan grup üyeleriyle de kısa enformel görüşmeler yapılmıştır.

Verilerin Analizi sürecinde; topluluk iç dinamiklerine sadık kalınmış ve elde edilen verilerin ortak noktaları üzerinden çeşitli kategorilere ve açıklayıcı kavramlara ulaşılmıştır. Dey'in (1993’ten akt. Özdemir, 2010: s. 330), nitel analiz sistematiği çerçevesinde betimleme, sınıflandırma ve ilişkilendirme aşamalarında analiz gerçekleşmiştir. Genel olarak betimlenen ve kültüre işaret eden veriler, kendi aralarındaki ortak kategorilerin işaret ettiği üst kategorilere ait biçimde sınıflandırılmış ve son olarak kategoriler arasındaki ilişkileri içeren kodların anlamı deşifre edilmiştir.

Araştırma Etiğinin Sağlanması ve Üye Kontrolleri sürecinde; Araştırma boyunca, 
araştırmacının kimliği gizlenmeyerek sayfa yöneticilerine araştırmanın amacı hakkında bilgi verilmiş, gruba katılım ise araştırmacıların gerçek profil hesabı kullanılarak gerçekleştirilmiştir.

Gizli bir izleme süreci olarak tasarlanmayan araştırma süreci başlamadan önce sayfa yöneticileriyle iletişime geçilerek, toplulukla ilgili yapılması planlanan araştırma hakkında detaylı bilgi verilmiş ve veri toplamaya ilişkin izinler alınarak sayfaya üye olunmuştur. Aynı şekilde paylaşımları ya da yorumları hakkında düşünceleri alınmak için ulaşılan grup üyelerine de araştırmanın amacı bildirilmiştir. Araştırma içerisinde hiçbir kullanıcının kimliği açıklanmamış, tüm üyelere ulaşarak yoklama yapılması mümkün olmadığı için üye kontrolleri yalnızca çalışmada verileri paylaşılacak olan üyeleri kapsamıştır.

Netnografi yöntemiyle yürütülen bu çalışmanın, kültürel deneyimlere ve birikimlere karşı tarafsızlığı savunan bilimsel perspektifi gereği, kimlikler arasındaki nefret söylemleri ve diğer türden karşılıklı pejoratif söylemler kapsam dışı tutulmuştur. Bu çalışmada bir grubun dijital eylem referanslarıyla betimlenen ve kültürel örüntüleri açıklanan engelli kimliği, yalnızca araştırmada saptanan bulgular çerçevesinde anlamlıdır ve dijital platformlardaki tüm engelli kullanıcı pratiklerini kapsamaz. Farklı sosyal oluşumlardaki kullanıcı motivasyonlarının ve kimlik odaklı kültürel paylaşımların etkisinde daha farklı sonuçların belirmesine, engelli kimliğinin farklı ifade biçimlerine ve göreli tutarsızlıkların tespitine muhtemel bakılmaktadır.

\section{Bulgular ve Tartıșma: 'Müstakbel' Kimlik Düșleri ve Evliliğin Öteki (N)etnografisi}

Bulgular ve Tartışma başlığı altında, "Dostluk Arkadaşlık sohbet İzdivaç evlilik ve engelli aşk" topluluğu ve alt grupları olan evlilik topluluklarının bir sosyal ağ sitesi olarak Facebook'taki kültürel üretim performansları, kimlik mantaliteleri, uzlaşı ve normalleşme konularında kullanıcılarının kendi aralarındaki meşgaleleri ve diğerleri ile itibar dengelemede kat ettikleri dijital katmanlar incelenmiş, çeşitli kategoriler ekseninde tartışılmıştır. Bu topluluğun en önemli özelliği, çoğunluğu oluşturan kimlik temsilinin bilinenin aksine engellilerden oluşması ve egemenlik mücadelesine taraf olanlar arasındaki azınlık-çoğunluk meselesinin baş aşağı edildiği bir cemiyet kurulumu barındırmasıdır.

Topluluk sayfasını tanımlayan demografik kodlar ilk bakışta, en belirgin özelliğin 'normal(!)' olarak addedilen kimliklerin aksine engelli olma haliyle ölçülebilir. Bu nedenle toplumsal cinsiyet, meslek, eğitim, uyruk gibi demografik bileşenlerin engellilik durumunun baskın kasveti karşısında öne çıkamadığı durumlar yaşanabilir. Bu dijital sosyalde söz konusu kurucu ilişki bağı evlilik ya da en azından flört tabanlı etkileşimler olduğu için cinsiyet ve diğer demografinin de 'engellilik' çatısı altında ifade edilmesinin önü açılır. Ağırlıklı olarak erkek kullanıcıların katılım gösterdiği topluluğun üyeleri engelli bekâr ya da boşanmış üyelerden oluşmaktadır. Grubun yöneticilerinden Limitless, grup içerisindeki paylaşımlardaki erkek baskınlığını, "Bayanlar yorum yapmaya korkar, sadece özelden paylaşır, yorum yapınca tüm sapıklar dolar" şeklinde açıklamaktadır. Bu söylem, engellilerin 'sapık' olma potansiyeli taşıdığına ilişkin bir ideolojik yaklaşımdan izler taşıması nedeniyle ilgi çekicidir. Bu tarz paylaşımlara bakıldığında asılında burada 
da farklı bir çatışma edimi görülür: kadın-erkek. Erkekler sayfa içerisinde rahatlıkla yorum yapıp evlenmek istediklerini, arkadaş aradıklarını belirtebilmektedirler. Ancak kadınlar benzer yorumlar yaptıklarında genellikle trol zannedilmekte ve gerçek kişi olmadığı düşünülerek altında farklı bir şeyler aranmaktadır.

Topluluğun varoluş nedenini ve katılma durumunu belirleyen ortak nokta "engelli olma" ve arkadaşlık, evlilik olgularıdır. Topluluğun temel yapısını oluşturan bu olguların yanında sayfaya ağırlıklı olarak hakim olan "dini değerlere bağlılık" durumudur. Grup üyeleri ağırlıklı olarak bu kavramlar altında "biz" bilincine sahip olurken, bu sayılan özelliklerin dışında kalan kişiler "öteki" olarak nitelendirilmektedir. Bu durum ilgili bölümde detaylı olarak örneklerle açıklanmaktadır.

\subsection{Toplanmanın İtkileri, Cemiyet Motivasyonu ve Örgütsel Düzenleyiciler}

Bir araya gelen bütün topluluklarda olduğu gibi 'Dostluk Arkadaşlık sohbet İzdivaç evlilik ve engelli aşk' topluluğunu da bir araya getiren ve grup üyelerini bir arada tutan belli başlı amaçlar vardır. Engelli bireylerin Goffman'ı da anımsatan (2014: s. 51) kendi deyimleriyle "kendileri gibi bireyleri" bularak dostluk, arkadaşlık oluşturmaları ve evlenmeleri grubun ana amacını oluşturmaktadır. Bu amacın yanında göze çarpan bir diğer baskın amaç, engellilerin kendilerine toplumsal bir alan oluşturarak seslerini duyurma çabası ve isteğidir. Bu her iki amaç da topluluk içindeki paylaşımlarda sürekli olarak vurgulanmaktadır.

Sayfa içerisinde siyasi paylaşımlarda bulunulmaması özel olarak belirtilmektedir. Bu düzenleyici, Türkiye'deki yaygın politik kutuplaşmanın engelli kimliği üzerindeki deformatif etkilerini asgariye indirme stratejisi ile ilintili düşünülebilir. Çünkü mevcut siyasetin tüm tarafları, kimlikler arası mücadelede ayrışmanın ve ötekileştirmenin başat araçlarından biri gibi davranan kitle hareketleri üretmektedir. Sayfa düzenleyicileri, mevcut gerilimler ve tansiyonlar arasındaki tetikleyici olaylardan kaçınmak ve sistemin hassas karnından uzak durmak amacıyla siyasete ket vurması, kimliğin normalleşmesi için önemli bir sansür ve oto kontroldür. Çünkü bu sansür, kimlik hakkında neyin konuşulacağı kadar ne hakkında susulacağının da belirleyeceği bir iyileşmenin umudu olarak paylaşılmaktadır.

Yöneticiler topluluğun amaçlarını, öncelikli olarak tanışma, dostluk kurma ve sonuç olarak evlenme olarak ifade etmektedir. Yöneticiler, bu grubu genel grup olarak tanımlayarak, öncelikli amacın evlilik olduğunu ancak bu grupta kişilerin amaçlarını anlayıp daha özel küçük gruplarına daha sıkı denetimlerle kabul ettiklerini bildirmiştir. Bir nevi inisiyasyon içeren bu çoklu katmanlar/mekanlar (Manovich, 2006: s. 221) arası geçiş, yeni medyanın hibrit ve geçişken mekan/arayüz tasarımlarının da bir göstergesidir ve bu şekilde kültürel üretimlerde modülerliğin, bölümlerin ve daha fazla otonom aksiyonların oluşması beklenir.

Topluluğun amaçlarını gerçekleştirip gerçekleştirmediğiyle ilgili sorulara grup yöneticisi Limitless", "Evlilikler çok fazla gerçekleşmiyor, 10 bin de 2 kişi evleniyor. Ancak daha bu hafta sonu bir düğündeydik. Geçtiğimiz ay da Ahmet ve Melike evlendi” şeklinde ce-

4 Çalışma içerisinde belirtilen tüm adlar, kişilerin kimliğini gizli tutmak amacıyla verilen mahlaslardır. 
vap vermektedir. İncelenen bu grup ve altındaki grupların tamamının yönetim ekibinde olan Liquid Boundary ise "Kurduğum bütün engelli gruplarının değişik amaçları vardır, evlilik gruplarında insanları bir araya getirmek, evlendirmek, gerektiğinde iş bulmak, yardım almasını sağlamak, bunları gerçekleştiriyoruz ve bir kişiyi bile mutlu etsek ben mutlu olurum" şeklinde amacını açıklamaktadır. Bu açıklama, engelli bireylerin sosyal medyayı bir kanal ve birleşme formülü olarak çeşitli fonksiyonlar ve kültürel örüntüler bütünü olarak düşündüklerini de gösterir.

Grubun yöneticileri tarafından grup içerisinde uyulması gereken kurallar maddeler halinde belirtilmektedir. Grubun yapısı kapalı gruptur. Yani grup içerisindeki bilgilere ve üyelere erişebilmek için gruba üye olmak gerekmektedir. Gruba katılım yönetici onayına bağlıdır.

Grubun kuralı açıktır... 1-Burada kimse kimseyi rahatsız edemez 2-Sayfa ve grup yayını yapılam...az... 3-Küfür edilemez... 4-Telefon numarası gibi özel şeyleri gidin başka yerlerde yazışın bu grupta olmasına asla müsade edilemez.. 5-Grup aleyhine yorum yapılamaz 6-Burası kimsenin oyun alanı değildir olgun olmayan insan gider... 7-Adminlerle kimse tartışamaz..... 8-Sohbet,müzik,resim ve şiir yayın hakkına sahipsiniz ancak bunlar ahlak kuralları içersinde abuk sabuk yayın yapan anında gruptan çıkarılır... 9-Burası siyaset alanıda değildir.siyasi görüşler yayınlanamaz... 10-Grupta kimse kimsenin "canısı, cicisi, şekeri, tatısı vs...değildir...!!! arkadaşlar adam gibi yorum yazın tanımadığınız insanlar hakkında laubali tavır ve davranışlar içine girmeyin aksi hallerde gruptan ya kendi isteğinizle yada adminler tarafından atılırsınız. 11- tüm bu kurallara uymayanlar gruptan atılırlar [YÖNETIM].

Yukarıdaki kati kurallar, normalde esnek oldukları gözlenen sanal topluluk yapılarına karşılık biraz daha geleneksel durmaktadır. Kurallar bildirgesindeki dilin ve söylemin yapısı, yasaklayıcı kuralların kapsamı, yaptırımların net ifadesi, ilişki biçimlerinin kenarlıkları gibi birçok durum, sondaki 'YÖNETIM' mahreci ile otoriter bir anlayışın tezahürleridir. Deklarasyonda en çok dikkat çeken noktalar ise dil kullanımını belirleme yaklaşımı ve yaptırımlardır. Özellikle 'sayfadan atılma' yaptırımı, normal olma umudunun kaybedildiği ve hayalin dağıldığı anı simgeleyen bir gerçekliğe dönüşün umutsuzluğunu ve karamsarlığını başlatabilir. Çünkü engelli bireyler için normallik hislerinin üretildiği çok az alan vardır ve bu alanlardan birinden dışlanmak/atılmak, telafisi zor travmaları tetikleyebilir. Ancak yöneticiler bu kaidelerin oluşmasında, kontrolü çok zor bir kitlenin birbirlerine yönelik dilsel yozlaşmalarını ve kimlik kırıcılıklarını engelleme davranışının belirleyici olduğunu argüman göstererek kendi gerekçelerini üretmektedir. 'Yöneticilerle kesinlikle tartışma yapılamayacağı' kaidesi ise askeri disiplinlerden dini nizamlara kadar uzanan geniş bir kontrol düzeneğinin gözetim ve denetim pratiğini canlı tutarak iktidar ilişkilerinin baş göstermesini kolaylaştırır. Böylece rahatlamak ve özgürleşmek isteyen engelli bireyler için tam anlamıyla baskıdan ve denetimden kurtuluş yaşanmaz.

Grup içerisinde yöneticiler gibi üyeler de paylaşım yapabilmektedir. Grup yöneticileri, bu grupta paylaşım yapmayı özellikle serbest bıraktıklarını, bu grupta insanları ayıklayarak diğer özel gruplarına yönlendirdiklerini ifade etmişlerdir. Bahsedilen diğer özel gruplarda üyeler paylaşım yapamamakta sadece yöneticiler paylaşım yapa- 
bilmektedir. Paylaşımlara müdahale konusunda ise 'Grup içerisinde yapılan olumsuz paylaşımlar zararsız ise müdahale edilmiyor ancak onur kırıcı ya da başka kişilere zarar verici olduğu durumlarda kişiler gruptan atılmakta ve gerektiğinde hukuki süreçler başlatılmaktadır' şeklinde belirtilen yönetici görüşü, doğrunun, iyinin, yanlışın ve kötünün dozajına karar vermedeki yönetici etkinliğini de özetler.

Grup içerisindeki paylaşımlarda fazla sayıda trol olduğu görülmektedir. Yöneticiler ve üyeler, bunun nedenlerinin başında dolandırıcılık geldiğini söylemektedir. Topluluk üyesi Semra, dolandırıcılık durumlarını başına gelen bir olayla şöyle örneklendirmektedir;

Geçenlerde bir tanesi bana yazmış, yok şurada yaşıyorum şuradan şu kadar para kaldı Kuran'a Allah'a yemin şu kadar ipoteği var şu kadar bana gönder ben sana iki misli veririm vallahi billahi Kuran din iman, bizim millet Kuran'ı dini görünce sanıyor ki gerçek.

Grup yöneticilerinden Liquid Boundary, trollere gerektiğinde müdahale yaptıklarını ifade ederek "Karşıdaki trolse yüzde 99 engellidir. Psikolojisi bozuk olduğundan, topluma çıkamadıklarından psikolojileri bozuk ve onlara dokunmuyorum ancak kişilere zarar verici bir durum varsa hukuksal mücadele başlatıyorum" şeklinde durumu tarif etmektedir. Bu tarif, dijital bağlamdaki ilişkilerin zaman zaman geleneksel bağlamdaki hukuksal denetleyiciler ile temas kurduğunu da belirtir.

Grup yöneticileri kendi kişisel sayfalarını kullanmaktadır. Grup yöneticilerinin kimlikleri açıktır. Ancak araştırma sırasında görüşülen grup üyelerinin büyük bir bölümünün gerçek hesaplarını gizleyerek farklı hesaplar açıp gruba üye oldukları görülmüştür. Bunun nedeni olarak da çevrelerindeki kişilerin yanlış anlamasından endişe etmelerini göstermişlerdir.

\subsection{Dilsel Pratiğin İnșası: 'Sözcüklere’ Takılmadan Ilerlemek}

Topluluk içerisinde genel itibariyle hatalı yazımlara ve ifade kalıplarına dayalı bir dil yapısı kullanılmaktadır. Sayfa yöneticileri bu durum için, "bu kişiler evlerinden çıkmıyor. Eve kapalı bir biçimde yaşamlarını sürdürüyorlar. Eğitim durumları ve iletişim becerilerini de mevcut durumları etkiliyor" demektedir. Bu tespitin doğruluğu varsayılarak, sayfa içindeki söz eylemlerde belirginleşen söylemsel sürçmeleri ve gramer eksikliklerinin eğitim ile yakın bir ilgileşim kurduğu ifade edilebilir. Sayfadaki dilsel pratikte yaygın görülen kullanım eğilimlerine örnek olarak; 'Hayirli akşamlar arkadaşlar benim günlümde güzümde engelli bir bayan altın gıbıdir ne kadar toprağa düşsede altın aynı altın demi' ya da 'herkeze hayırlı guner ismim Ayşe cidi bir yuva içinburdayi [...] allahin huzurunda yalan dolan asla olmadi olmazda sakin alaha inancı korkusu olan gelsin dinine bal olan igunde kutu günde [...] yaş sorun deyil insan olsun yeter cidi olanları bkm simdi allaha emanet olun'ifadeleri gösterilebilir.

Gruba genel itibariyle nezaket içeren bir konuşma yapısı hâkimdir ancak bazı kullanıcıların sinirlendiklerinde ya da hoşlarına gitmeyen bir paylaşım söz konusu olduğunda ağır küfürleri alenen ettikleri gözlemlenmektedir. 


\subsection{Kültürel Paylașımları Haritalamak: İlișkiler Sistematiği, 'Bizlerin' Normalliği ve Anormal 'Ötekiler'}

Grup içerisinde yapılan paylaşımların genel yapısına bakıldığında ağırlıklı olarak tanışma ve evlilik amaçı paylaşımların ön plana çıktığı görülmektedir. Paylaşım alanlarında yoğun olarak dini paylaşımlar da yapılmaktadır. Yapılan evlilik paylaşımları da dâhil paylaşımların çoğunluğuna dini bir kimlik hâkimdir.

Grubun kapak fotoğrafı incelendiğinde grubun öncelikli amacı kendisini net bir biçimde göstermektedir. Bu fotoğrafta ve grubun vitrinindeki görsellerin hiçbirinde engelli olmanın gösterenlerine yer verilmemesi dikkate değer bir ayrıntıdır.

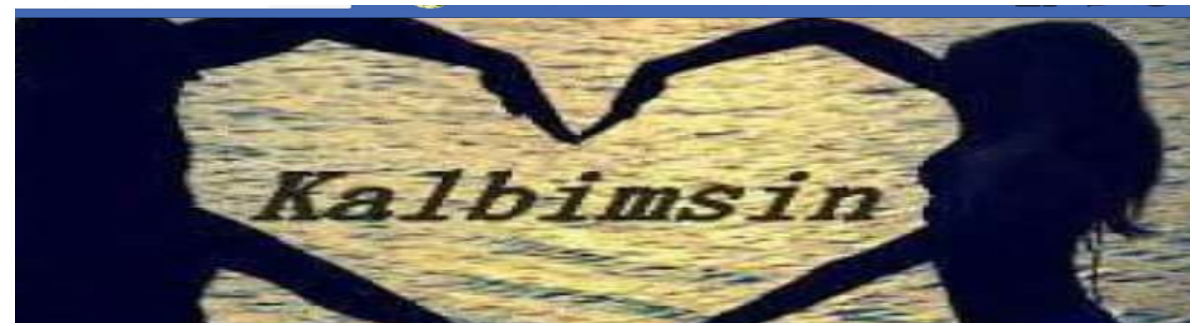

Görsel 1. Grubun Kapak Fotoğrafı

Bazı paylaşımlarda da engellilere yönelik yapılan olumsuz davranışları içeren haberlere yer verilmektedir. Bu tür paylaşımların altına yoğun bir şekilde küfür yazılmaktadır. "Onlar" dedikleri kendilerinden ayrı kabul ettikleri diğerlerine buradan nefret söylemlerinde bulunmaktadırlar. Bu durum Goffman nazarında (2014), damgalanan bireylerin kimi zaman 'el mi yaman, ben mi yaman' dercesine hasmane bir tutumla kendilerini ötekileştiren kişilere karşı saldırgan tavır takınmaları olarak tahlil edilen olaylara da örnek oluşturur.

Bu paylaşımlara ek olarak, devletten yapılacak yardımlara yönelik soruların da sık olarak paylaşıldığı görülmektedir. Bu noktada grubun üyeleri ikiye ayrılmaktadır. Bir bölümü yardım almak için uğraşırken diğer bir bölümü de bu paylaşımların altına "ben çalışıyorum sen de çalışsana” gibi yorumlar yazmaktadır. Bu iki cenahın paylaşımları değerlendirildiğinde, birinci cenah olan yardım almayla ilgili yoğun paylaşım yapan cenah toplumun kendisine atfettiği ötekiliği kabul ederek bunu bir acizlik, yardım edilmesi gereken durum olarak değerlendirmektedir. Ancak engel durumu bu paylaşımları yapan kişilerden daha fazla olan kişileri de barındıran diğer grup çalışabileceğini, toplumda yer alabileceğini ifade etmektedir.

Grup içerisinde yoğun olarak kullanılan "onlar" diye başlayan cümlelerde ötekileştirme net bir biçimde görülmektedir. "Öteki" diye bahsedilen genel itibariyle engelli olmayan bireylerdir. Bunun yanında grup, erkek egemen bir gruptur ve söylemleri arasında kadın-erkek ötekiliği de göze çarpmaktadır. Dini paylaşımların yapısına bakıldığında dinine bağlı kişiler olduğunu söylemlerine ve paylaşımlarına taşıyan kişiler evlilik şartında "dinine bağlı", "namaz kılan" gibi ifadeler kullanarak bu noktada da gizil bir ötekileştirme yapmaktadırlar.

Yorumları dikkat çeken bazı üyelere yöneltilen neden sanal ortamlarda bir araya 
gelmeyi tercih ettikleri sorularına 'dışarıya çıkmaya çekindikleri, burada kendileri gibi olanları daha rahat buldukları, burada herkesin aynı olduğu, kendilerini rahat ifade edebildiklerini, gerçek topluluklarda kendilerine yer bulmakta zorlandıklarını' ifade etmektedirler. Bu gerekçeler, sosyal medyanın, geleneksel ilişkilerde zedelenen kimliğin onarıldığı ve bazı ilişkilerin ya da ilişkisizliklerin yarattığı boşlukların, 'kendine benzeyenlerle' telafi edildiği bir yer olarak benimsenmesini örneklemektedir. Bu durumu grup üyesi Mustafa şu şekilde ifade etmektedir: "Gerçek ortamlarda bu insanlar bazı şeylerden dışlanmışlar. Engellileri kolay kolay çok yerde kabullenmiyorlar özellikle iş aşk ve evliliğe gelince. Burada yüzde 90 kendileri gibi insanlar yer almakta."

Bu gruplarda bir araya geldiklerinde kendilerini daha rahat ifade ettiklerini söyleyen kullanıcıların oldukça rahat paylaşımlarda bulunarak, buna uygun açıklamalara yöneldikleri görülmektedir. Burada birlikte olmaktan güç alan grup üyeleri, kendi ötekilerini oluşturarak, organik hayatta kendileri öteki konumundayken bu toplulukta engelli olmayanları öteki olarak seçmekte istekli davranmaktadır. Buna örnek olarak; 'Bizler sizlerin oyuncağı değiliz, bizlerde sizin gibi insanız hep unutulduk ama istesenizde istemesenizde bizlerde sizlerle eşit haklara sahibiz' ya da 'siz neden arıyon diye sormak yerine atlıyorsunuz biraz kendinize gelin burdakiler dışardakilerden havalı' gibi kanaat bildirimleri gösterilebilir. Bu durumlar ilgili yapılan paylaşımlarda, "biz engelliyiz, onlar özürlü", "Bir gün onlarında başına gelince görürler", "Yarın kimin ne olacağını (onlar) bilemezler" şeklinde doğrudan ya da dolaylı bir tepkisel boşalım gözlenmektedir.

Beden üzerinden tahakküme maruz kalan engellilerin oluşturduğu bir sosyalde, beden üzerinden ötekileştirici temsiller üretilmesi çalışma süresince saptanan en ilginç kimlik kodlarından biridir. Toplumun 'kendini normal kabul edenleri' tarafından dışlanmaktan, zor duruma düşürülmekten rahatsızlık duyan gruptaki bir paylaşımda kilolu bir kişinin fotoğrafı seçilerek altına "gruba katılmak istiyor kabul edeyim mi” şeklinde not düşülüp eklenmiş̧tir. İlgili görsel aşağıda sunulmuştur.

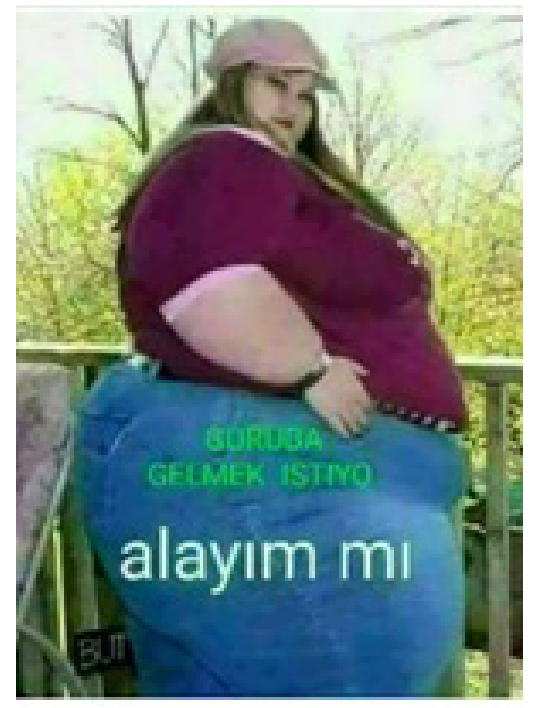

Görsel 2. Ötekileştirmenin Bedensel Hali 
Burada dikkat çeken bir diğer nokta, grup içindeki bazı üyelerin, grubun diğer üyelerini nasıl ötekileştirdiğiyle ilgilidir. Araştırmacı açık kimliğiyle grup üyeleriyle kontak kurduğunda bu durum daha açık bir şekilde kendisini göstermektedir ve bir anda grubun diğer üyelerinden "onlar" diye bahsetmeye başlamaktadırlar. Bu konuşmalarda grubun üyelerini eleştirmekte, "eğitimsiz", "cahir" ve "yobaz" kişiler olarak değerlendirmektedirler. Bu tarz bir eğilim, kimliğin yüz yüze kaldığı dışlamaya karşılık egemeni kabullenen kitlelerin, kendi aralarından suçlu arama motivasyonu olarak birçok öteki grupta görülen yaygın davranışlara neden olmaktadır. Böylece ötekileştirmeye neden olan asıl durum görmezden gelinerek, tüm suç/günah içeriden birine yüklenmeye çalışılır.

\subsection{Evlilik Olgusunun Günlük Tezahürleri ve Ritüeller Üretimi}

Araştırılan gruplarda evlilik şartları ve oluşum şekli organik yaşamdan ya da diğer evlilik sitelerinden daha farklı işlemektedir. Yeni medyayla birlikte insanlar kendilerine giydirdikleri sanal kimliklerle kendilerini çekinmeden, daha rahat biçimde ifade etme imkânına kavuşmuşlardır. Paylaşılan evlilik isteklerini içeren paylaşımlara bakıldığında belli başlı ortak özelliklere sahip oldukları görülmektedir. Üyeler kişisel bilgilerini paylaşırken öncelikli olarak vurguladıkları özellik engelli olma durumlarıdır. Bunu "\%30 engelliyim", "Görme engelliyim" gibi tanımlayıcıları ve engellilik derecelerini anlatacak terimleri kullanarak ifade etmektedirler. Burada evlilik birliğinin kurulmasındaki ilk ritüel engel durumlarının bilinmesi, birbirlerine uygunluğu ya da birbirlerine engel teşkil edip etmemesiyle ilgilidir.

Evlenilecek kişilerde aranan özelliklerden bir diğeri dinine bağlılık şartıdır. Paylaşılan evlilik isteklerinin tamamına yakınında bu durum göze çarpmaktadır ve değişik cümlelerle ifade edilmektedir. Evlilik şartları içerisinde bu durum için "namaz kılan", "dinine bağlı", "tesettürlü" gibi tanımlayıcı sıfatlar dili kendini üretmektedir.

Evlilik şartları arasında vurgulanan bir diğer nokta da 'dürüstlüktür'. Dürüstlük kavramı istisnasız bir biçimde her mesajın içerisinde yer almaktadır. Bu kavram, engellilerin maruz kaldıkları dışlayıcı pratikler döngüsünde ve sosyal medyadaki bedensizliğin sebep olabileceği 'trol' faaliyetlerinin baskısında dolaşan tekinsizliğe yönelik bir kültürel refleks olarak değerlendirilebilir.

Belirtilen bu ritüellerle ilişkili olarak göze çarpan bir diğer husus, bu üç noktada taviz vermeyeceğini belirten üyelerin diğer hususların hiçbir öneme sahip olmadığını vurgulamalarıdır. Bu durum, mesajlarında belirttikleri "bekar, dul fark etmez", "Başka şehre de giderim, hangi şehir olursa olsun giderim", "İç güveysi bile gelebilirim" gibi ifadelerden de anlaşılmaktadır.

Engelli üyelerin öz sunumları, tıpkı televizyonlarda bir döneme iz bırakan evlilik programlarında görülen tanıtım ritüellerine bağlı olarak 'yaş, kilo, engel oranı, cinsiyet' gibi bilgiler içeren dijital kimliklerle başlamakta ve paylaşım altına yapılan yorumlarla kamusallık özellikleri kazanmaktadır. Evlilik sunumlarının kamusal alanda başlayan duyurumları, 'ilgilenen özelden yazsın' biçimindeki notları ile özel alana taşınmaktadır. Kadın üyelerin paylaşımları daha fazla etkileşim üretirken, asıl konuşmaların özel mesaj ekranından (Messenger) ya da cep telefonlarından gerçekleştiği yöneticiler ve 
üyelerce tasdik edilmektedir.

Sayfada erkekler özgürce ne istediklerini ifade edip, bu durum normal karşılanırken, kadın üyeler aynı istekleri ifade ettiğinde onlarca yorum almanın yanında eleştirel yaklaşımlarla da karşılaşmaktadırlar. Erkek egemen yapının oluşumu bu grup içerisinde de kendisini açık bir biçimde göstermektedir.

\section{Sonuc}

Çalışmanın bulguları, sosyal medya toplumsallığının geleneksel bağlamlı formel ve enformel ilişkiler için bir telafi düzeneği içerdiğini ve engelli bireylerin kolektif katkılarıyla üretilen 'kimlik ideallerinin' jeneriklerini göstermek için güçlü bir aracı olduğunu gösterir. İlk bakışta ütopya gibi görünmesi muhtemel olan sosyal medyatik telafi alanlarının, Foucault'un heterotopya önermesi hatırlandığında, aslında heterotopya gibi davrandıkları fikri daha makul bir zemine yayılır. Foucault'a göre (2005: s. 295-296), ütopyalar toplumsal yaşamın karşısında olduğu düşünülen olumsal, ancak gerçekte var olmayan yerleri tarif ederken, heterotopyalar da aynı şekilde karşıtlığı ancak gerçekte var olmayı kast eder. Sosyal medya, organik gerçekliğin kimi zaman tam olarak karşısında durabilen, ancak bir hayli gerçek 'başka' yerlerdir; yani heterotopyalardır. Nitekim sosyal medyayı bir heterotopya/başka yer olarak değerlendiren Göker (2017), bu mekânlarda olup bitenlerin Foucault'un kavramsallaştırdığı heterotopya teoriği ile bağıntılı olduğunu söyler. Çünkü dijital heterotopyalar da tıpkı geleneksel türdeşleri gibi farklı mekânları tek bir deneyime açarak yalıtılmış, başka türden ve alışıımışın dışında kalan davranışlara mekânlık/yurtluk eder. Bu bakımdan incelenen topluluğun siber mekân deneyimindeki kimlik düşleri, egemen görüşün dışında kalan ötekiler açısından bir kalkışma olması itibariyle heterotopik/başka yerlere ait birer pozitif ya da ideal imgelem gibi düşünülmelidir.

Göker'e göre (2017), heterotopyalar, sapma davranışların kümelendiği, zaman ve mekân algısının farklılaştığı ve kimliklendirici yerler olması bakımından yeni medya ile örtüşen bir mekân algısı üretmektedir. Bu mekânlarda, toplumun geri kalanından farklı bir kültür üretilmesi mümkündür ve genellikle de öyle olur. Çünkü buralarda gözetim ve denetim mekanizmasının baskın etkisi sönümlenir ve düzenleyici sitemler heterotopik kişilikler tarafından yeniden kurgulanır. Esasında incelenen topluluk aksiyonlarında gerçekleşen de tam olarak bu duruma işaret etmektedir. Üstelik heterotopyanın mekânsal bir terminoloji olarak yeniden düzenlenmesinin öncesindeki kullanılış biçiminin, tıbbi patolojilerin bir kolu olan organik bozukluklarla ilişkili olması da engellilerin heterotopik deneyimlerine rassal bir orantı kazandırır. Nihayetinde, bedende kendiliğinden oluşan hastalıklar, kontrol dışı virüsler, fazladan organlar ve olması gereken yerden farklı bir noktada yer alan organizma parçaları heterotopya olarak tanımlanır (Adal, 2002: s. 24). Engelli bireylerin hem dirimsel hem de sosyal medyatik birer heterotopya ile ilintili olmaları, kimliğin 'başka', 'öteki' ve 'yabancı' olarak tanınmasında etkilidir.

İncelenen topluluk sayfasının 'kapalı grup' özellikleri ile kurgulanması da tesadüf değildir ve heterotopik bilinci içerir. Çünkü Foucault’a göre (2005: s. 300), heterotopyalara kolaylıkla ve değirmene girer gibi girilemez. Buralarda ya rıza dışı kalınır ya da herkese açık olsa bile genellikle ‘öteki' olanların dolaştığı mevkiler olarak içe kapanma 
hareketi sergiler. Engelli topluluklarına engelli olmadan da girmek mümkündür. Ancak orada geçirilen süre zarfında engelli bireylerden biri gibi olmak ya da oradan çıkmak arasında bir tercih yapmak zorunda kalınır. Nitekim bu tip tecrit alanlarında başarılı olmanın en önemli göstergesi orayı terk etmektir (Wacquant, 2011: s. 170). İncelenen topluluk normalleşme kaygısında olanların geçiş yani marjinallik sürecini içerir. Evlenmek normalleşmeye denk düşünüldüğünde, evlenen kişi için orada bulunmanın da bir bağlayıcılığı kalmaz. Bu nedenle heterotopyalar, 'öteki' bir gerçek mekân olmanın pek de ötesine geçemez, normalleşemez, doğası itibariyle normal değildir.

Topluluk içi aktivitelerde görülen dini kod üretiminin kimlik açısından tedavi edici olduğu pek çok psikolojik ve sosyolojik faydası listelenebilir. Ancak gözlemlere dayalı bir yorumsama çerçevesinde, dini kod üretimini de bir tip hetetoropik durumla ilintilendirmek mümkündür. Çünkü dijital heterotopyanın başka nitelikte mekân olmasından doğan bedensizlik otonomisi ile teolojik inancın ölüm sonrasında vaat ettiği bedensiz ve eşitlikçi yaşam arasında bir bağ kurulabilir. Rasyonalitede bedensel kusurların eşitsizlik yaratması olağan kaide iken, tinsel toplum tasarılarında bedenselliğin ruhsal yaşam karşısındaki belirleyiciliği sorgulanabilir. Kimlik düzeyinde eşitlenmeyi bekleyen engelli inançlılar, harekete geçip kendi heterotopyalarında bedensizliği deneyimleyerek bir yanılgının umudundan mutluluk devşirebilir. Yine de bedenin sosyal medyatik sunumundaki esneklik, engellilerin kendilerini görünüş anlamında da dönüştürmesinin imkanlarını barındırır.

Asıl amaç olarak topluluk jeneriğine konulan evlilik teması, kimliğin cinsiyet ilişkileri ve diğer sosyal ilişkilerin de içerildiği bir dizi engelli öz-temsilleri çerçevesinde normalleşme, normal olmayı deneme ya da kurgulama çalışması tarafından arkada bırakılmaktadır. Bunun için sayfa yöneticilerinin ‘ 10.000 kişide 2 kişi evleniyor’ söylemi ve gözlem verilerindeki düşük flört izlenimlerini düşünmek yeterli olabilir. Kimliğin mürüvvetini görmek için kendileri ve kendilerinden olmayanlar ile ilgili öznel tasarılarını sosyal medyatik yaratılara dönüştürerek iliş̧i nesnelerine sahip olan engelli kullanıcılar, esasen kendilerini normal hissettikleri bir formda görülmektedir. Bu durum, bir dönem televizyon ekranlarında önemli bir alan kaplayan evlilik programlarına benzeşir. Çünkü o programlarda da evlenmek, program içi tele-kimliklerin sonuna gelindiğinin ve ayrılarak 'gerçek' dünyaya geri dönüşün simgesidir. Program içinde uzatılan flörtler ve bir türlü gerçekleşmeyen evliliklerin bağlı oldukları bu önerme, incelenen topluluktaki ilişkilere de görece sirayet edebilir. Ancak bu konuda bir şerh düşmek gerekirse, görüşülen sayfa yöneticileri, sayfanın bazen amacının dışına çıktığını kabul etseler dahi genellikle amacına ulaştığını ifade etmektedirler. Bu durumu, yapılan evliliklerden örnekler vererek açıklamaktadırlar. Bu sayfada engellilerin sadece engellilerle değil, engellilerin engelli olmayanlarla da evlilik yaptıklarını da sözlerine eklemektedirler. Ancak gözlem süresince bu tarz bir söylemi destekleyen bulguya rastlanmadığını belirtmek gerekir. Çünkü bu durum, engelliler için yalnızca birer istisnadır, mutlak olan ise, engellilerin yine kendileri gibi 'engelli olanlarla' evlenmesidir. Toplumsal kimlik sorunlarının bir karşılığı olan bu düşünce, siyahilerin genellikle siyahilerle evlenmesi gibi bir normallik olarak algılanır. Bu yönüyle sayfa içinde üretilen evlilik normlarının ve cinsiyet ilişkilerinin geleneksel kavrayışa zıtlık üretmediği ve birçok birikimin tekrar edildiği görülmektedir. Bu duruma bir diğer örnek olarak, sayfa içinde evlilik söz konusu olduğunda eşcinsel 
gibi belirtilerin marjinal kabul edilerek dışlanması gösterilebilir. Kadın ve erkek kimliği arasına indirgenen evlilik, eşcinselliği marjinal olarak tanımlayan ancak marjinalliğin ileri boyutunu yaşayan engellilerin 'normalliği' ne kadar özümsediklerini de sorgulatan bir meseledir. Normalleşen madunluk, sosyal medya ağlarındaki özerk toplumsal kurulumlarda bile çeşitli kabullenişler ve koşullu çaresizlikler zinciri olarak kendini yeniden üretir.

Sonuç olarak, engellilerin gündelik yaşamlarında çekilmeye zorlandıkları heterotopyalarından farklı olarak normalleşmeye aracılık eden dijital heterotopyaları, yalnızlığa karşı birleşme, çoğalma ve çoğunluğu oluşturma güdüsünü evlilik akdi ile bütünleştiren bir kurguda şekillenir. Bu kurgu, evliliğin ufuktaki bir amaç olarak ideale dönüştüğü ilişki prensiplerinde engelli kimliğini normal ve engellenemez bir tertiple yeniden yapılandırır.

\section{Kaynakça}

Adal, R. (2004). Aydınlanma Çağında Kamusal Alan ve Heterotopik Mekân Incelemesi: Palais Royal ve Mason Locaları. Yayımlanmamış Yüksek Lisans Tezi. Ankara: Ankara Üniversitesi Sosyal Bilimler Enstitüsü.

Binark, M. (2014). Yeni Medya Çalışmalarında Araştırma Yöntem ve Teknikleri. İstanbul: Ayrıntı Yayınları.

Bourdieu, P. (1985) The Genesis of the Concepts of Habitus and of Field, Sociocriticism. Theories and Perspectives, 2(2): pp. 11-24.

Bouerdieu, P. (1986). Forms of Capital. J. G. Richardson (Eds). The Handbook of Theory and Research for the Sociology of Education. California: Greenwood Press.

Bouerdieu, P. (2002). Masculine Domination. Palo Alto: Stanford University Press.

Burcu, E. (2017). Türkiye'de Engelli Bireylerin Dezavantajı Konumlarına Engellilik Sosyolojisinin Eleştirel Tavrılya Bakmak, Toplum ve Demokrasi, 11(24): s. 107-125.

Castells, M. (2000). The Rise of The Network Society. $2^{\text {nd }}$ Eds. Cambridge: Blackwell Press.

Cirhinlioğlu, Z. (2001). Sağlık Sosyolojisi. Ankara: Nobel Yayınları.

Clement, J. (2019). Most Popular Social Networks Worldwide as of July 2019, Ranked By

Number Of Active Users (In Millions). Retrieved from https://www.statista.com/statistics/272014/ global-social-networks-ranked-by-number-of-users/ link at 05 September 2019.

Connolly, W., E. (1995). Kimlik ve Farkııık, Siyasetin Açmazlarına Yönelik Çözüm Önerileri. Ferman Lekesizalın (Çev.). İstanbul: Ayrıntı Yayınları.

Donath, J., S. (1998). Identity and Deception in The Virtual Community. P. Kollock and M. Smith (Eds.). Community in Cyber Spaces. London: Routledge.

Duman, N., A. ve Doğanay, G. (2017). Toplumsal Dışlanma Pratikleri Üzerinden Trabzon'da Engelli Kadınlar. Sosyoloji Araştırmaları Dergisi, 2 (20): s. 1-48.

Foucault, M. (1972-1977). Power/Knowledge: Selected Interviews and Other Writings. Colin 
Gordon (Eds.). New York: Pantheon Books.

Foucault, M. (1992). Hapishanenin Doğuşu. Mehmet Ali Kılıçbay (Çev.). Ankara: İmge Yayınevi.

Foucault, M. (1997). The Birth of Biopolitics. Paul Rabinow (Eds.). Michel Foucault, Ethics:

Subjectivity and Truth. New York: The New Press, pp. 73-79.

Foucault, M. (2005). Özne ve İktidar. M. Ali Kılıçbay (Çev.). İstanbul: Ayrıntı Yayınları.

Fuchs, C. (2007). Transnational Space and The Network Society. 21st Century Society, 2 (1): pp. 49-78.

Fuchs, C. (2009). A Contribution to the Critique of the Political Economy of Transnational Informational Capitalism. Rethınkıng Marxısm. 21 (3), (JULY): pp. 387-402.

Fuchs, C. (2017). Google Kapitalizmi. Filiz Aydoğan (Ed.). Yeni Medya Kuramları. İstanbul: Der Yayınları. s. 71-83.

Goffman, E. (2014). Damga Örselenmiş Kimliğin Idare Edilişi Üzerine Notlar. Ş. Geniş, L. Ünsaldı, S.N. Ağırnası (Çev.), Ankara: Heretik Yayınları.

Göker, G. (2017). Dijital Heterotopyalar: Başka Bir Bağlamda Yeni Medya. Selçuk IIletişim Dergisi. 9(4): s. 164-188.

Hancock, P. (2000). The Body, Culture and Society. Buckingham, Philedelphia: Open University Press.

Heidegger, M. (2018). Varlık ve Zaman. Kaan Ökten (Çev.). İstanbul: Alfa Yayınları.

Keskin, S. ve Kaya, U. (2018). Sosyal Ağ Otobanlarının Otostopçuları: Interrail Türkiye Topluluğunda Gezgin Kültürü. M. Gökhan Genel (Ed.). İletişim Çağında Dijital Kültür. Konya: Eğitim Yayınevi. s. 233-257.

Kozinets, R., V. (1998), On Netnography: Initial Reflections on Con-sumer Research Investigations of Cyberculture. Advances in Con-sumer Research, 25: pp. 366-371.

Levinas, E. (1998). Humanism of the other. Illionis, USA: University of Illionis Press. Levinas, E. (2014). Ölüm ve Zaman. Nami Başer (Çev.). İstanbul: Ayrıntı Yayınları. Manovich, L. (2001). The Language of New Media. Cambridge, Massachusets: MIT Press. Manovich, L. (2006). The Poetics of Augmented Space. Visual Communication, 5 (2): pp. 219240.

Manovich, L. (2012). How To Follow Software Users. 3 Eylül 2019 tarihinde http://manovich.net/ index.php/projects/how-to-follow-software-users adresinden ulaşıldı.

Manovich, L. (2016). Designing and Living Instagram Photography: Themes, Feeds, Sequences, Branding, Faces, Bodies. 3 Eylül 2019 tarihinde http://manovich.net/content/04projects/097-designing-and-living-instagram-photography/instagram_book_part_4.pdf adresinden ulaşıldı.

McDonald, M. (2006). Empire and Communication: The Media Wars of Marshall McLuhan. Media, Culture and Society. London, Thousand Oaks and New Delhi: SAGE Publications. 
Meltzer, A., L. (2010). Body Image and Marital Satisfaction: Evidence for the Mediating Role of Sexual Frequency and Sexual Satisfaction. Journal of Family Psychology 24(2): pp. 156-64

Nazlı, A. (2012). Öteki Beden: Bir Ötekilik Biçimi Olarak Engelli Beden ve Engellilik. Sosyoloji Dergisi, 27: s. 15-32.

Özdemir, M. (2010). Nitel Veri Analizi: Sosyal Bilimlerde Yöntembilim Sorunsalı Üzerine Bir Çalışma. Eskişehir Osman Gazi Üniversitesi Sosyal Bilimler Enstitüsü Dergisi, 11 (1): s. 323343.

Özmen S. ve Keskin, S. (2018). Sosyal Medyada Öz-Temsil ve Ötekiliğin 'Öteki Boyutu’: Karikateist Toplumsalı Üzerine İnceleme. IntJCSS. 4 (2): s. 533-558.

Poster, M. (1979). Ciritical Theory of The Family. London: Pluto Press.

Rabinow, P. and Rose, N. (2006). Biopower Today. BioSocieties, 1: pp. 195-217.

Sartre, J. P. (2009). Varlık ve Hiçlik. Türkan Ilgaz ve Gaye Çankaya Eksen (Çev.). İstanbul: İthaki Yayınları.

Tremain, S. (Eds.) (2005). Foucault and The Goverment of Disability. Michigan: University of Michigan Press.

Wacquant, L. (2011) Kent Paryaları, IIleri Marjinalliğin Karşıllaştırmalı Sosyolojisi. Mehmet Doğan (çev.), İstanbul: Boğaziçi Üniversitesi Yayınevi.

Weber, M. (1947). The Theory of Social and Economic Organization. (Trans.) A. M. Henderson and Talcott Parsons. New York: Oxford University Press.

Wellman, B. and Gulia, M. (1999). Net Surfers Don't Ride Alone: Virtual Communities as Communities. Peter Kollock and Marc Smith (Eds.). Communities as Cyberspace. New York: Routledge. pp. 1-26.

Yanıklar, C. (2014). Sanal Topluluklar ve Geleneksel Topluluklar Arasındaki Farklılıkların Sosyolojik Bir Analizi. Sosyoloji Araştırmaları Dergisi. 17 (1): s. 159-190.

https://www.facebook.com/groups/722273404553620/ adresinden ulaşıldı. (05.09.2019). 